\title{
The principle of effective stress and triaxial compression testing of peat
}

$1 \quad$ Lin Zhang BEng

Postgraduate student, Department of Civil, Structural and Environmental Engineering, Trinity College Dublin, Ireland
2. Brendan C. O'Kelly MEngSc, PhD, FTCD, CEng Associate Professor, Department of Civil, Structural and Environmental Engineering, Trinity College Dublin, Ireland
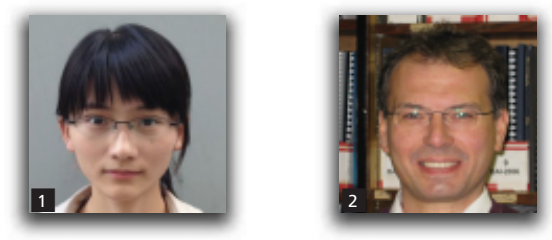

Peat deposits comprise the fragmented remains of dead plant vegetation that have accumulated under waterlogged conditions. Effective stress theories developed for mineral soils are routinely applied in practice for peat, although there are fundamental issues regarding the application of conventional soil mechanics to peat, on account of its extremely high water content, fibrous nature, low shear strength and high compressibility, and also the flexible, permeable and compressible nature of the porous organic solids. This paper presents an experimental study intended to contribute to the ongoing and increasing debate about the degree to which conventional soil mechanics approaches can be applied to peat. A programme of isotropic consolidated-drained triaxial compression tests was performed on saturated fibrous peat under the same effective confining pressure, but developed by applying different cell- and back-pressure combinations. Effects of mini-structure and fibre content on mechanical response were considered by testing undisturbed, reconstituted and refined (blended) peat materials. Similar volumetric strain-time and stress-strain-time responses experienced by identically prepared triaxial specimens were persuasive regarding the applicability of the principle of effective stress to peat, although there is no firm conclusion, since significant challenges occurred in performing these tests and in interpreting the data.

\section{Notation}

$B \quad$ Skempton pore-pressure coefficient

$C_{\mathrm{c}} \quad$ primary compression index

$C_{\mathrm{c}}^{*} \quad$ primary compression ratio

$C_{\mathrm{sec}} \quad$ secondary compression ratio

$C_{\alpha} \quad$ coefficient of secondary compression

$c^{\prime} \quad$ effective cohesion

$D$ diameter

$E_{\mathrm{v}}^{\prime} \quad$ drained modulus of elasticity

e void ratio

$H$ height

$K_{0} \quad$ at-rest earth pressure coefficient

$s_{\mathrm{u}} \quad$ undrained shear strength $\sigma_{\mathrm{v}} \quad$ vertical stress

$\sigma_{\mathrm{v}}^{\prime} \quad$ effective vertical stress

$\sigma_{3} \quad$ confining pressure

$\sigma_{3}^{\prime} \quad$ effective confining pressure

$\sigma_{3 \mathrm{f}}^{\prime} \quad$ applied lateral effective stress at failure

$\phi^{\prime} \quad$ effective angle of shearing resistance

\section{Introduction}

Effective stress defines the distribution of stresses acting between the solid particles and the pore fluid in soils. The principle of effective stress (Terzaghi, 1923) consists of the definition of effective stress (i.e. in the case of full saturation, effective stress equals the total stress minus the pore water pressure) and the fact that it correlates with mechanical behaviour to a sufficiently high degree over the stress range of engineering interest (Lambe and Whitman, 1969), exclusively controlling certain aspects of mineral soil behaviour, notably strength and compressibility. In recent years, peat soil problems, including dyke failures, foundation failures and landslides, have focused greater attention on understanding the mechanical behaviour and properties of peat and other highly organic soils. Peat deposits comprise the fragmented 
remains of dead plant vegetation at various stages of decomposition that have accumulated in mire (Hobbs, 1986).

Effective stress theories that have been developed for mineral soils are routinely applied in practice for peat (e.g. Baird and Gaffney, 1994; Cola and Cortellazzo, 2005; Hanrahan, 1954; Hebib and Farrell, 2003; Hemond and Goldman, 1985; Yamaguchi et al., 1985), although to the authors' knowledge the appropriateness of these theories for peat has not been validated experimentally. There are fundamental issues regarding the application of conventional soil mechanics to peat on account of the material's extremely high water content, fibrous nature, generally partially saturated state due to ongoing biodegradation of the solids, very low shear strength and high compressibility, as well as the flexible, permeable and compressible nature of the porous organic solids themselves. In the case of mineral soils, Monte and Krizek (1976) defined the flow limit (i.e. four to five times the liquid limit value) as the water content at which slurry starts to behave as soil, with the application of the principle of effective stress valid for water contents below this state transition. The water content of peat can range from a few hundred per cent of dry mass to greater than $2000 \%$ (Hobbs, 1986). Also, for finegrained mineral soils, researchers have heuristically modified the principle of effective stress to account for physico-chemical forces at particle-size level (Bennethum et al., 1997). Owing to the extreme porosity and high organic content, these physicochemical forces should not be ignored when considering the mechanical behaviour of peat. According to Landva and Pheeney (1980), capillary stresses in peat could be of the same order of magnitude as occurs in compression under an applied stress of $7 \mathrm{MPa}$. Although the rate of decomposition of the solids is extremely slow under waterlogged (anaerobic) conditions in situ, it may increase significantly should environmental factors become more favourable (Pichan and O'Kelly, 2012, 2013). Hence, following from the reasons outlined above, the direct application of conventional soil mechanics theories to peat soils may be questionable. In fact, some researchers have stated their doubt, although to date they have not reported any complete experimental or in situ proof, nor rational theoretical explanations. Bishop and Eldin (1950) have shown that in order for the principle of effective stress to be valid, the solid particles must be assumed incompressible, which is certainly not the case for peat. Hobbs (1986) did not cover shear strength in his treatise on peat, for the reason that conventional effective-stress strength was not only determined by the state of effective stress but was also time dependent, with the void ratio peat continuously decreasing under maintained load.

Furthermore, peat deposits are generally heterogeneous, with large variations occurring over very small distances (Landva, 1980), because plants of different character live in communities, and the rate of decomposition is not uniform, but rather is patchy throughout the peat mass (Hobbs, 1986). This presents a great challenge in studying the geotechnical behaviour of peat, particularly at laboratory-scale level.
In this paper, the validity of applying the principle of effective stress to saturated peat soils was investigated through a programme of one-dimensional compression tests and isotropic consolidated-drained triaxial compression tests on a particular pseudo-fibrous peat. Effects of mini-structure and fibre content on the mechanical response were considered by testing undisturbed, reconstituted and refined (blended) peat materials. The study presupposes that the effective-stress strength parameters $\left(c^{\prime}, \phi^{\prime}\right)$ are appropriate for peat, and furthermore, by implication, that these parameters can be obtained from consolidated-drained triaxial tests.

\section{Description of peat test material}

The test material was pseudo-fibrous peat obtained from Clara bog (County Offaly, Ireland), a raised bog that originated from an early Holocene lake circa 11500 years ago and which subsequently infilled, forming a fen about 8000 years ago (Crushell et al., 2008). Saturated intact blocks of peat were obtained from a waterlogged, recently cut vertical face-bank at a depth of $2.5 \mathrm{~m}$ below the ground surface. The peat blocks were excavated using a flat shovel and trimming saw in order to prevent sampling disturbance. The blocks were sealed with preservative film immediately after sampling and kept in sampling boxes during transportation and subsequent storage in the laboratory. The fossilised laminates consisted mainly of Sphagnum mosses, but also some sedge, and were interspersed with plant and shrub (Calluna) remnants, along with a small portion of woody fibres provided by shrub rootlets. Hence the undisturbed peat was heterogeneous, although with a general cross-anisotropic fabric on account of the pattern of accumulation of the different vegetation in situ. The material was classified as $\mathrm{SCN}-\mathrm{H}_{4}-\mathrm{B}_{3}-$ $\mathrm{F}_{3}(\mathrm{~S})-\mathrm{R}_{1}(\mathrm{~N})-\mathrm{W}_{1}(\mathrm{~N})$ on the extended von Post peat classification system (Landva and Pheeney, 1980).

\section{Experimental programme}

Sets of test-specimens having similar physical properties were prepared from peat cakes that had been formed under onedimensional compression. These specimen sets were then isotropically consolidated in the triaxial apparatus under different cell pressures, and finally sheared at the same strain rate in drained triaxial compression. The applied back-pressure was such that all of the specimens experienced the same state of effective stress during isotropic consolidation and shearing. Hence the principle of effective stress would imply that the specimen sets should experience the same mechanical response, which includes consolidation-time and stress-strain-time behaviours, given that the specimens had been designed to be physically identical and have the same stress history. The triaxial apparatus was chosen since the applied stress and specimen boundary conditions are well defined, and the repeatability of the test method is good.

The test specimens were sheared at a sufficiently slow rate under drained conditions in order to allow direct measurement of the effective-stress shear response. Shearing of the consolidated specimens at a slow rate in undrained compression would have 
resulted in an applied lateral effective stress at failure $\left(\sigma_{3 \mathrm{f}}^{\prime}\right)$ of essentially zero, irrespective of the value of the applied cell pressure. This occurs since the induced pore water pressure rapidly builds up to approximately equal to the cell pressure for axial strain $\left(\varepsilon_{\mathrm{a}}\right)$ of greater than 5-10\% (Hanrahan, 1954; Marachi et al., 1983), on account of the low Poisson's ratio of the peat fibres (Farrell, 2012), with maximum strength mobilised for $\varepsilon_{\mathrm{a}} \gg 15-20 \%$. Hence, unlike conventional geomaterials, it is not possible to determine values of $c^{\prime}$ and $\phi^{\prime}$ for peat from consolidated-undrained triaxial compression testing with pore water pressure measurement, given $\sigma_{3 \mathrm{f}}^{\prime} \approx 0 \mathrm{kPa}$ is mobilised in peats for different values of applied cell pressure.

\subsection{Material treatment and index properties}

The sampled peat material was treated in different ways in order to allow consideration of mini-structural and fibre effects. The first specimen set (undisturbed) was carved from the block sample. Material for the second set (reconstituted) was obtained by crumbling the peat, which required the addition of some bog water for thorough remoulding. Water from its natural source was used, since some engineering properties (e.g. value of liquid limit; Hanrahan et al., 1967) are sensitive to the chemistry of the water. Material for the third set (refined peat) was prepared by blending some reconstituted material using an electric, hand-held blender, having removed any large fibres beforehand using tweezers. A relatively homogeneous paste was obtained for testing by gently pressing and rubbing this blended material to pass the $425 \mu \mathrm{m}$ sieve. The purpose of this preparation method was to remove the coarse fibrous fraction, with $\sim 36 \%$ of the original reconstituted material (wet mass basis) removed in obtaining the refined material.

Scanning electron microscope images of the materials are shown in Figure 1. The fibres were observed to remain largely intact for reconstituted material, compared with the short, serrated fibres and cellular/spongy matrix of the relatively homogeneous, refined peat material.

Table 1 lists selected index and physico-chemical properties of the different peat materials. The water content $(w)$ was determined by oven-drying representative specimens at $105^{\circ} \mathrm{C}$ over a period of $48 \mathrm{~h}$. Although some of the constituent solids in peat are susceptible to slight charring/oxidation at this drying temperature (O'Kelly, 2004, 2005a), values of water content determined under these test conditions were sufficiently accurate. This was confirmed from analysis of water content data for test-specimens of the same peat material determined for different combinations of oven-drying duration and set temperatures over the range of $60-110^{\circ} \mathrm{C}$. The refined peat had rather unusual behaviour during oven drying, in that this material became extremely brittle and shattered easily. Similar behaviour has been reported for amorphous organic clays derived from the production of potable water at municipal treatment works (O'Kelly, 2008, 2013).

The determination of the Atterberg consistency limits of peat is



(a)

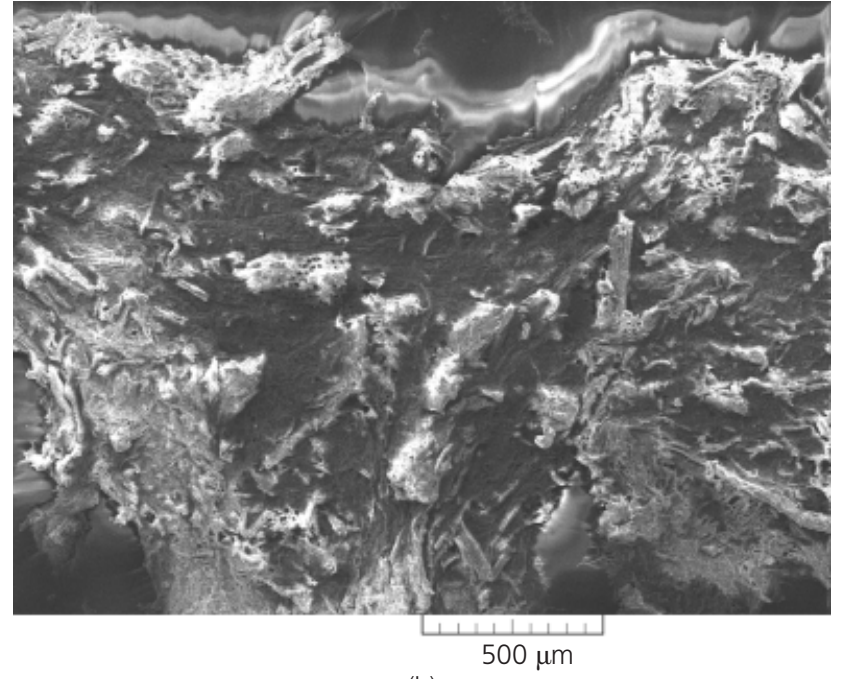

(b)

Figure 1. Scanning electron microscope images of peat materials: (a) reconstituted; (b) refined

complicated on account of its high organic and fibre contents. An experimental study into the determination of the liquid limit (LL) of peat using the fall-cone LL apparatus, considering five different techniques for preparing the sample material for testing, was reported by Yang and Dykes (2006). In the present study, the values of LL and plastic limit (PL) were determined using the $80 \mathrm{~g}, 30^{\circ}$ fall-cone LL apparatus and Casagrande thread-rolling method (BS 1377-2: BSI, 1990a). The reconstituted material for the LL test was prepared by the method of preparation described by Skempton and Petley (1970) and Hobbs (1986): first removing any large fibres using tweezers (i.e. test material still included some elements greater than $425 \mathrm{~mm}$ in size) and then thoroughly mixing the remaining material using a spatula. The significantly higher LL value measured for reconstituted material using the fall-cone method presumably reflects the effect of these coarser elements, which were absent from refined material (O'Kelly, 2013). Uniform 


\begin{tabular}{lcc} 
Property & \multicolumn{2}{c}{ Peat type } \\
\cline { 2 - 3 } & $\begin{array}{c}\text { Undisturbed (U) and } \\
\text { reconstituted (R) }\end{array}$ & Refined \\
\hline Water content: \% & $590(\mathrm{U}), 1026(\mathrm{R})$ & 1065 \\
Liquid limit: \% & $1135(\mathrm{R})$ & 757 \\
Plastic limit: \% & Non-plastic & 446 \\
Plasticity index & - & 311 \\
Specific gravity of solids & $1 \cdot 42$ & 1.42 \\
Loss on ignition: \% & 98.6 & 98.5 \\
Fibre content: \% retained on $63 \mu \mathrm{m}$ sieve & 74.2 & $27 \cdot 1$ \\
Fibre content: \% retained on $150 \mu$ m sieve & 63.5 & 16.7 \\
pH & 3.8 & 3.7 \\
Table 1. Selected properties of peat materials & &
\end{tabular}

soil threads of undisturbed and reconstituted materials could not be rolled out to $3 \mathrm{~mm}$ in diameter on account of the fibrous nature of these materials, which were therefore categorised as non-plastic. It can also be argued that the LL and PL conditions are defined for fine-grained mineral soils, with specific physical meaning, and that these Atterberg limits should not be applied to peats and other highly organic soils (O'Kelly, 2013). For instance, the bulk refined material could be easily remoulded at water contents significantly below the measured PL value.

The specific gravity of solids was determined using the small pyknometer method. The loss on ignition was determined by igniting dry powdered material in a muffle furnace at $440^{\circ} \mathrm{C}$ (BS 1377: BSI, 1990a, 1990b). The fibrous material was separated by washing representative specimens on the $150 \mu \mathrm{m}$ sieve (as specified by ASTM, 2008), and also on the $63 \mu \mathrm{m}$ sieve in order to assess the effect of the blending action. The fibre content (FC) was determined by expressing the oven-dried mass of material retained on the sieves as a percentage of the specimen dry mass at $105^{\circ} \mathrm{C}$. The in situ peat was classified as Hemic (33\% $<$ FC $<67 \%)$ according to ASTM (2007). The undisturbed undrained shear strength $\left(s_{\mathrm{u}}\right)$ of the in situ deposit was assessed by performing quick-undrained triaxial compression tests on $38 \mathrm{~mm}$ diameter test specimens that had been carved from the intact peat block. A peak undrained shear strength of $24 \mathrm{kPa}$ was mobilised at $\varepsilon_{\mathrm{a}}=16 \%$ under the cell pressure of $45 \mathrm{kPa}$ and strain rate of $120 \% / \mathrm{h}$ applied in these unconsolidated-undrained triaxial compression tests, with the shear plane inclined at an angle of $\sim 42^{\circ}$ to the horizontal direction.

As noted earlier, the sampled peat consisted mainly of Sphagnum mosses, which comprise a distinctive cellular/spongy fraction of mainly leaves, and a fibrous fraction of leaf stalks, stems and rootlets. A water content distribution test, performed after manually separating the fibrous and cellular/spongy fractions of a reconstituted peat sample, indicated $w \approx 940 \%$ and $1130 \%$ for the respective fractions, compared with the material's bulk water content of $1026 \%$. This broadly agrees with Landva and Pheeney (1980), who reported $w=900-1100 \%$ for Sphagnum leaves, compared with an average value of $670 \%$ for stems. The refined peat material had higher bulk water content, since it contained a greater cellular/spongy fraction.

\subsection{One-dimensional compression tests}

Consolidated cakes of reconstituted and refined peat materials were formed from which sets of physically identical specimens were prepared for isotropically consolidated-drained triaxial compression testing. Slurry specimens, $152 \mathrm{~mm}$ in diameter $(D)$ by initially $\sim 180 \mathrm{~mm}$ in height $(H)$, were prepared in a consolidometer cell (O’Kelly, 2009) by placing successive layers, $\sim 20 \mathrm{~mm}$ deep, that were individually lightly tamped and vacuumed to remove air voids. The vacuum was applied after fitting the lid of a vacuum desiccator above the rim of the consolidometer cell, which formed a temporary airtight seal. The peat cakes were formed by consolidating the slurry specimens one-dimensionally under applied vertical stresses $\left(\sigma_{\mathrm{v}}\right)$ of 6,12 and $24 \mathrm{kPa}$, which were maintained for periods of 15,16 and 43 days respectively, with vertical two-way drainage of the specimens to atmosphere. The initial specimen height was determined such that $76 \mathrm{~mm}$ long triaxial specimens could be carved vertically from the consolidated peat cakes.

\subsection{Consolidated-drained triaxial compression tests}

The isotropic consolidation and effective-stress strength properties were measured using a type of triaxial apparatus that included two pressure-volume controllers (GDS Instruments Ltd) that provided automatic control of the applied cell- and backpressures to an accuracy of $1 \mathrm{kPa}$, along with measurement of the specimen volume change response to an accuracy of $0.03 \mathrm{ml}$.

Sets of three reconstituted and refined triaxial specimens ( $D=38 \mathrm{~mm}$ by $H=76 \mathrm{~mm}$ ) were carved from the consolidated peat cakes. A set of three undisturbed triaxial specimens were also carved from the intact peat block. The undisturbed peat had 
an initial value of void ratio (e) of 8.4 and apparent preconsolidation pressure of $\sim 15 \mathrm{kPa}$, which was determined from an oedometer $e-\log \sigma_{\mathrm{v}}^{\prime}$ plot using the curve-fitting technique reported by Casagrande (1936).

The three triaxial specimens in each set were tested in series under the same effective confining pressure $\left(\sigma_{3}^{\prime}\right)$ of $30 \mathrm{kPa}$, achieved by applying cell pressures $\left(\sigma_{3}\right)$ of 45,245 and $1045 \mathrm{kPa}$ in combination with back-pressures $\left(u_{\mathrm{b}}\right)$ of 15,215 and $1015 \mathrm{kPa}$ respectively. Hence the overall testing duration for a given material type (including the consolidometer test with three load stages, followed by preparation and isotropically consolidateddrained triaxial compression testing of three specimens in series) was approximately 120 days. All of the triaxial tests, as well as the different stages of these tests, were of the same duration for consistency. The small stress increase that occurred between the final one-dimensional compression stage under $\sigma_{\mathrm{v}}=24 \mathrm{kPa}$ in the consolidometer and isotropic triaxial consolidation under $\sigma_{3}^{\prime}=30 \mathrm{kPa}$ was designed to produce a modest volumetric strain $\varepsilon_{\mathrm{v}}$ (i.e. test specimens would remain almost right cylinders, with $H: D$ ratio of approximately $2: 1$ ), from which an appropriate strain rate in triaxial compression could be determined by standard curve-fitting of the measured $\varepsilon_{\mathrm{v}}$ against elapsed time response (BS 1377-2; BSI, 1990c). The range of cell pressures adopted (which covered approximately three orders of magnitude) was limited at the upper end by the rated pressure capacity of the Perspex cell, and at the lower end by the control and measurement accuracy of the cell- and back-pressures. Specimen saturation was confirmed by measuring a pore pressure coefficient $B$ value of at least $0 \cdot 98$.

Filter-paper side drains were not fitted around the triaxial specimens, since relatively large corrections would then need to have been applied to the measured deviatoric stress, assuming the test specimens would respond by general barrelling under compression. Instead, all specimens were consolidated under the allaround confining pressure, with two-way vertical drainage, via porous stones, against the applied back-pressure. The consolidation stage lasted for a period of 3 days, during which the specimens' excess pore water pressure $\left(u_{\mathrm{e}}\right)$ response was periodically measured by temporarily closing the specimen drainage lines for a period of $\sim 30 \mathrm{~min}$ (O'Kelly, 2005b), after which time the $u_{\mathrm{e}}$ readings appeared to have started to equilibrate. Hence the average degree of consolidation $(U)$ for the saturated specimens was determined by

$$
\text { 1. } U=\frac{\sigma_{3}^{\prime}-u_{\mathrm{e}}}{\sigma_{3}^{\prime}}
$$

The rate of axial strain $\left(\dot{\varepsilon}_{\mathrm{a}}\right)$ of $0.085 \% / \mathrm{h}$ applied during the compression stage was based on the time period $t_{\mathrm{p}}$ required to achieve 'end of primary' during the preceding triaxial consolidation stage. 'End of primary' refers to the soil state corresponding to practically complete dissipation of the excess pore water pressures. Values of the time period $t_{\mathrm{p}}$ for the different specimens were determined from curve-fitting analyses of both the measured average degree of consolidation and volumetric strain responses against elapsed time. For the purpose of the calculations, failure of the specimens during the compression stage was assumed to occur for $\varepsilon_{\mathrm{a}}=20 \%$, which is often adopted as a limiting-strain condition in testing peats and other highly organic soils. The associated axial deformation of the specimens also approximately corresponded with the range of the instrumentation fitted on the triaxial cell. Standard factors were applied to the experimentally derived $t_{\mathrm{p}}$ values (in accordance with BS 1377-8; BSI, 1990c) to account for the particular specimen drainage conditions employed. The deduced rate of axial strain of $0.085 \% / \mathrm{h}$ in drained triaxial compression (i.e. stage duration of 10 days) would, in theory, allow substantive dissipation of excess pore water pressures to occur at $\varepsilon_{\mathrm{a}}$.

\section{Experimental results and analyses}

\subsection{One-dimensional compression}

Figures 2 and 3 show semi-log plots of cumulative strain against elapsed time and void ratio against effective vertical stress for the reconstituted and refined slurry cakes (with initial void ratios of 15.20 and 15.45 respectively) under one-dimensional compression.

As expected, compressive strains of the slurry cakes experienced by the end of the load stage under $\sigma_{\mathrm{v}}=24 \mathrm{kPa}$ were very large. The importance of structure was evident (see Figure 2), with the response clearly related to the performance of fibres, demonstrated by final $\varepsilon_{\mathrm{a}}$ values of $24 \%$ and $46 \%$ achieved for reconstituted and refined slurries respectively. Structural effects were significantly less for the refined material, since its constituent fibres had been serrated by the blending action, whereas the fibres had remained largely intact and randomly oriented for reconstituted material. The refined material also had a greater cellular/spongy fraction. The linear $e-\log \sigma_{\mathrm{v}}^{\prime}$ response measured for the refined slurry (Figure 3) indicates that this material behaved akin to fresh normally consolidated sediments, with $C_{\mathrm{c}}=6.5$ and $C_{\mathrm{c}}^{*}=0.40$ : where $C_{\mathrm{c}}$ and $C_{\mathrm{c}}^{*}$ are the primary compression index and compression ratio respectively. The response of reconstituted material was clearly different, presumably on account of mini-structural effects related to the arrangement of the coarse fibres.

Secondary compression settlement was clearly distinguishable towards the end of the load stage at $\sigma_{\mathrm{v}}=24 \mathrm{kPa}$, which had been maintained for an extended period of 43 days. Values of the coefficient of secondary compression (i.e. change in void ratio over one decade of time during the secondary compression phase) of $C_{\alpha}=0.45$ and 0.39 , and also of the secondary compression ratio $C_{\mathrm{sec}}=0.024$ and 0.027 (i.e. change in specimen height per unit height over one decade of time), were determined for reconstituted and refined materials respectively. Applying the $C_{\alpha} / C_{\mathrm{c}}$ concept gave experimental values of 0.06 and 0.07 , 


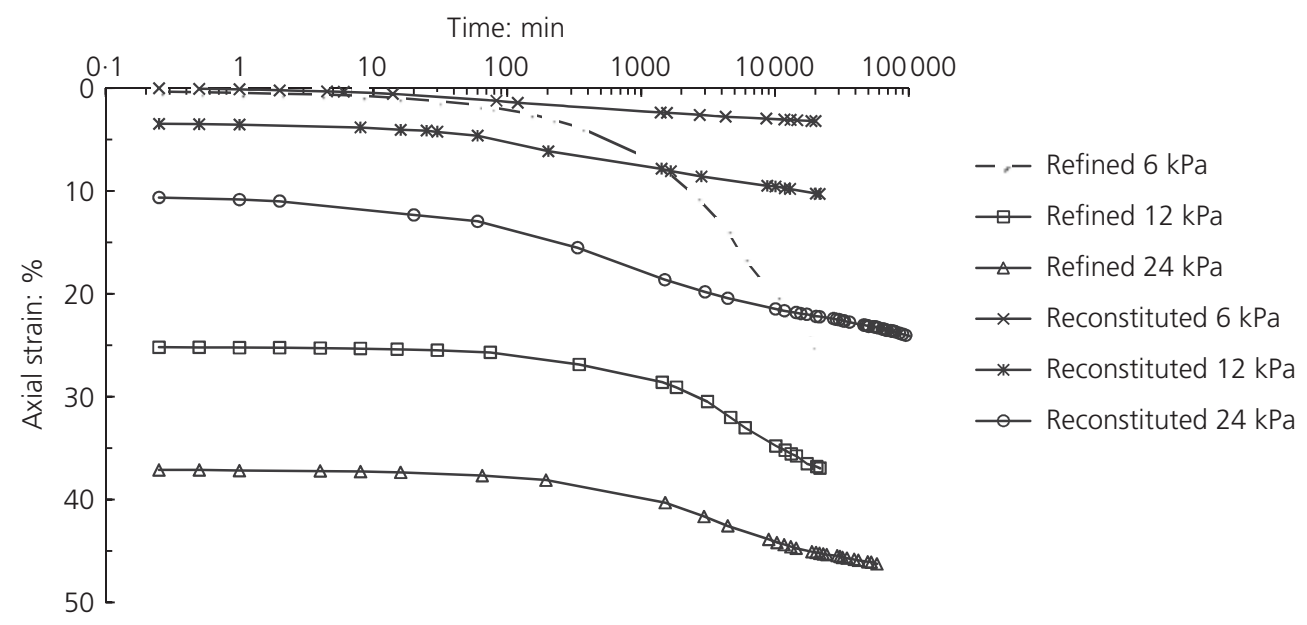

Figure 2. One-dimensional compression of peat cakes

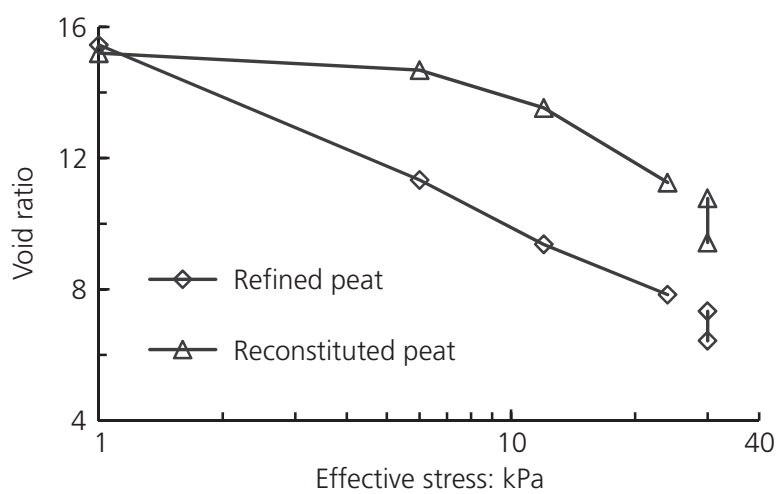

Figure 3. Void ratio against effective stress responses from onedimensional and isotropic consolidation tests

consistent with the range of $0 \cdot 06 \pm 0 \cdot 01$ reported for fibrous peats by Mesri and Ajlouni (2007).

\subsection{Consolidated-drained triaxial compression}

The values of water content and void ratio for undisturbed, reconstituted and refined specimens tested in isotropically consolidated-drained triaxial compression are listed in Table 2.
As expected, the greatest variability occurred for the undisturbed specimens, on account of the heterogeneity of the natural peat. Some small Calluna remnants that provided preferential flow channels were observed during the preparation of these undisturbed specimens, particularly for $\sigma_{3}=45 \mathrm{kPa}$ (Table 2), which may explain its higher initial void ratio value compared with the other two undisturbed triaxial test specimens.

Undisturbed specimens were observed to have a general crossanisotropic fabric; reconstituted specimens a general anisotropic fabric (i.e. the orientation of coarser fibres was not horizontal dominant), and refined specimens a general isotropic fabric. The average degree of specimen consolidation achieved against elapsed time during the triaxial consolidation stage is shown in Figure 4. Between approximately 800 and $1400 \mathrm{~min}$ were required for substantive dissipation $(>85 \%)$ of the excess pore water pressure. This is consistent with Yamaguchi et al. (1985), who reported periods of between 700 and 1000 min for dissipation of excess pore water pressure in undisturbed fibrous peat specimens $(D=50 \mathrm{~mm}$ by $H=125 \mathrm{~mm})$ under isotropic consolidation for $\sigma_{3}^{\prime}=70-100 \mathrm{kPa}$ and with side drains provided.

The volumetric strain $\left(\varepsilon_{\mathrm{v}}\right)$ response during the triaxial consolida-

\begin{tabular}{|c|c|c|c|c|c|c|c|c|c|}
\hline \multirow[b]{3}{*}{ Cell pressure: $\mathrm{kPa}$} & \multicolumn{9}{|c|}{ Material type } \\
\hline & \multicolumn{3}{|c|}{ Undisturbed } & \multicolumn{3}{|c|}{ Reconstituted } & \multicolumn{3}{|c|}{ Refined } \\
\hline & 45 & 245 & 1045 & 45 & 245 & 1045 & 45 & 245 & 1045 \\
\hline Initial water content: \% & 623 & 560 & 584 & 757 & 755 & 767 & 523 & 530 & 502 \\
\hline Initial void ratio & $9 \cdot 1$ & $8 \cdot 1$ & 8.4 & $10 \cdot 7$ & $10 \cdot 7$ & $10 \cdot 9$ & $7 \cdot 4$ & $7 \cdot 5$ & $7 \cdot 1$ \\
\hline Void ratio at end of consolidation stage & $7 \cdot 8$ & $7 \cdot 7$ & $7 \cdot 9$ & $9 \cdot 5$ & $9 \cdot 2$ & $9 \cdot 6$ & $6 \cdot 4$ & $6 \cdot 2$ & $6 \cdot 7$ \\
\hline Water content at end of compression stage: \% & 471 & 463 & 455 & 543 & 553 & 556 & 378 & 386 & 393 \\
\hline Void ratio at end of compression stage & $6 \cdot 7$ & $6 \cdot 6$ & $6 \cdot 5$ & $7 \cdot 7$ & $7 \cdot 9$ & $7 \cdot 9$ & $5 \cdot 4$ & $5 \cdot 5$ & $5 \cdot 6$ \\
\hline
\end{tabular}

Table 2. Water content and void ratio of triaxial specimens 


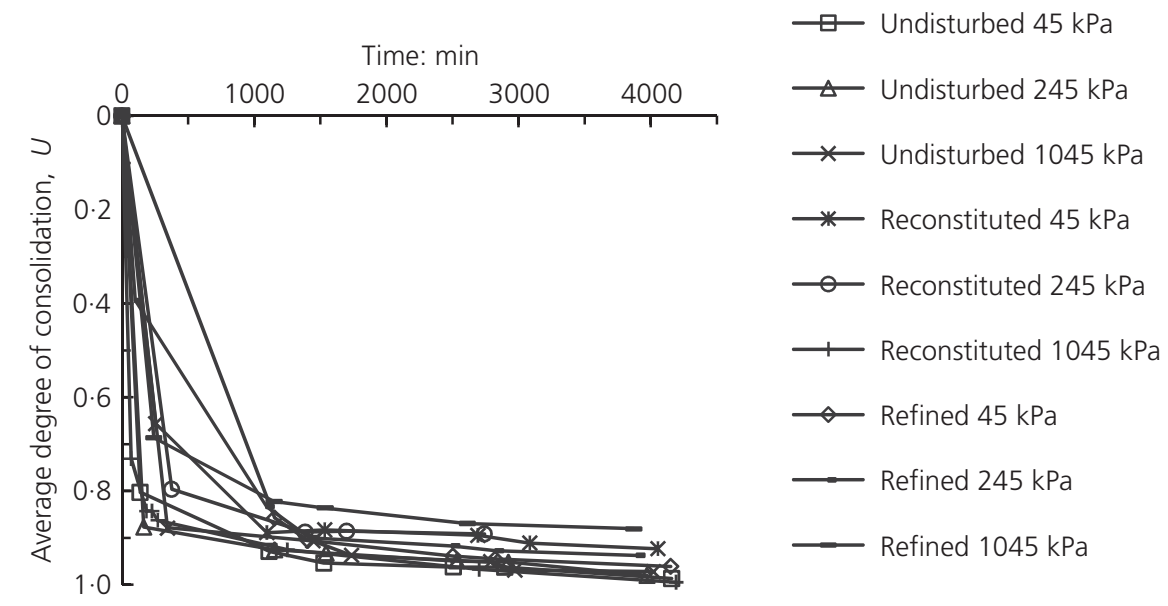

Figure 4. Average degree of consolidation achieved during

isotropic consolidation

tion stage is plotted against square root of elapsed time and logarithm of elapsed time in Figures 5 and 6 respectively. The $\varepsilon_{\mathrm{v}}$ response measured during the compression stage is also shown in Figure 6. Note that, for the consolidation stage, $\varepsilon_{\mathrm{v}}$ values were calculated on the basis of the initial specimen volume, whereas for the compression stage, $\varepsilon_{\mathrm{V}}$ values were calculated on the basis of specimen volume achieved at the end of the consolidation stage, in accordance with BS 1377-8 (BSI, 1990c). A slightly slower $\dot{\varepsilon}_{\mathrm{a}}=0.054 \% / \mathrm{h}$ was used in compression the refined peat specimen under $\sigma_{3}=45 \mathrm{kPa}$, compared with $\dot{\varepsilon}_{\mathrm{a}}=0.085 \% / \mathrm{h}$ used for all of the other triaxial specimens. Hence the rate of volumetric strain during compression of the refined $45 \mathrm{kPa}$ specimen was marginally lower than that measured for the refined $245 \mathrm{kPa}$ and $1045 \mathrm{kPa}$ specimens (Figure 6c).

The isotropic consolidation response was strongly related to the structure of the peat materials (Figures 4-6). Undisturbed specimens consolidated significantly more quickly than reconstituted specimens, presumably on account of the intact mini-structure of the former. Reconstituted specimens consolidated more quickly than refined specimens, presumably on account of the larger/ longer flow channels provided by intact coarse fibres present in the former. However, at any given elapsed time, the maximum difference in volumetric strain recorded among specimens of a given material set under the same value of effective stress was remarkably small, which is consistent with the principle of effective stress.

The deviatoric stress-strain responses of the peat materials are shown in Figure 7, with some diurnal cycling in the data caused by minor temperature changes in the laboratory that occurred over the course of the 10-day compression tests. Membrane corrections (BS 1377-8: BSI, 1990c) were not applied to the measured deviatoric stress values, since the specimens did not undergo barrelling-type failure typical of plastic soils but instead, after contracting radially during the triaxial consolidation stage, essentially underwent one-dimensional compression during the compression shearing stage.

For a given peat material, the deviatoric stress-strain responses for the set of three specimens tested under $\sigma_{3}^{\prime}=30 \mathrm{kPa}$ were similar, irrespective of the cell- and back-pressure combinations applied, which again is consistent with the principle of effective stress. The tests were terminated at $\varepsilon_{\mathrm{a}}=20 \%$, although the mobilised deviatoric stress continued to increase approximately linearly with axial strain. This eventuality was expected for undisturbed and reconstituted materials, since it is generally not possible to bring a fibrous peat specimen to failure in drained triaxial compression tests on account of continual compression of the fibres themselves (Farrell, 2012) and ongoing volumetric compression, even for $\varepsilon_{\mathrm{a}}=50 \%$ (McGeever, 1987). However, the response of the refined peat was somewhat unexpected, given that all of the constituent fibres were short in length, passing the $425 \mu \mathrm{m}$ sieve.

The drained modulus of elasticity $\left(E_{\mathrm{v}}^{\prime}\right)$ ranged from approximately 110 to $160 \mathrm{kN} / \mathrm{m}^{2}$ under $\sigma_{3}^{\prime}=30 \mathrm{kPa}$. The undisturbed, reconstituted (see Figure 8) and refined specimens generally responded by bulging slightly during compression, although essentially underwent $K_{0}$ compression, with no evidence of a shear plane developing.

\section{Discussion: effective stress testing in drained triaxial compression}

The conventional conception is that the undisturbed and reconstituted materials should mobilise higher shear resistance compared with the refined material, on account of fibre reinforcement. However, the response of the refined material ( $\mathrm{FC}=16 \cdot 7 \%$, compared with $63.5 \%$ for undisturbed and reconstituted materials) in drained triaxial compression was unexpected, with similar deviatoric stress values mobilised at a given strain level by undisturbed, reconstituted and refined materials for 


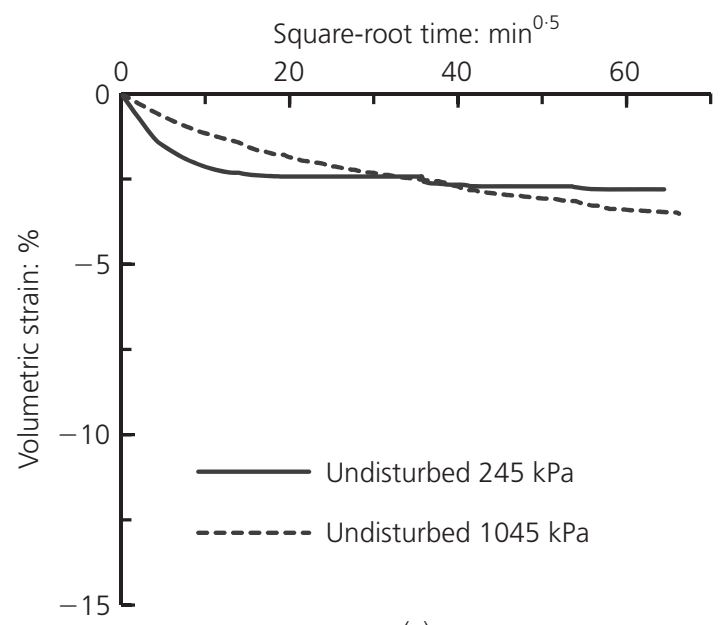

(a)



(b)

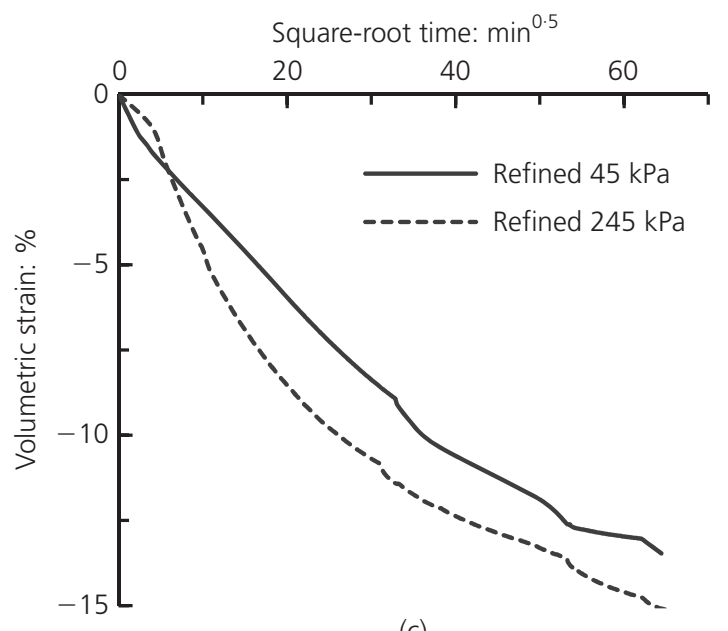

(c)

Figure 5. Volumetric strain against square root of elapsed time response under isotropic consolidation: (a) undisturbed;

(b) reconstituted; (c) refined

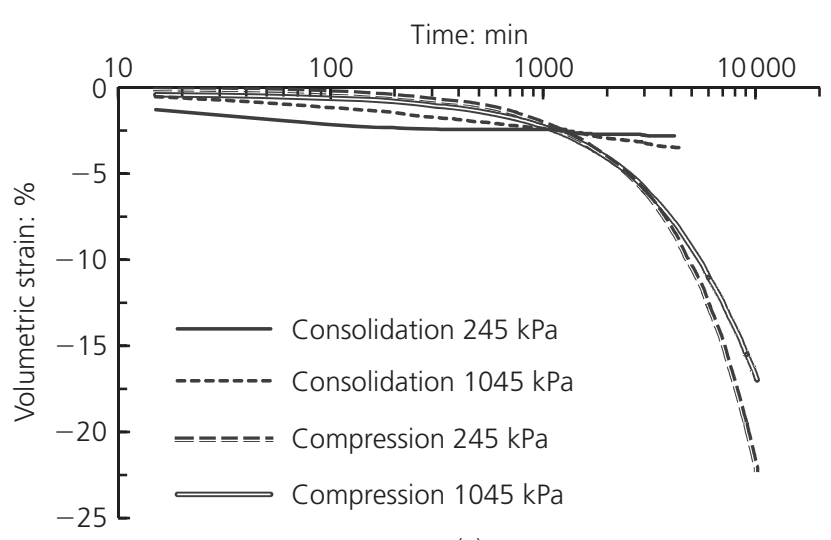

(a)



(b)

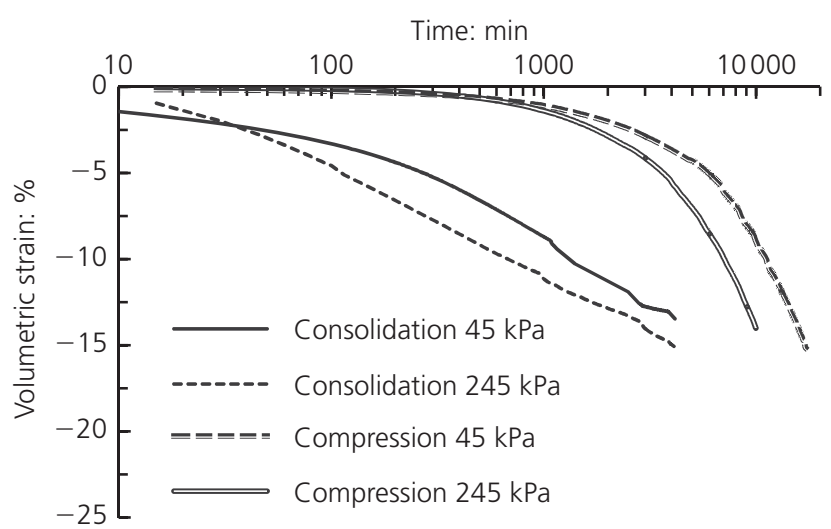

(c)

Figure 6. Volumetric strain against elapsed time responses for triaxial consolidation and compression stages: (a) undisturbed; (b) reconstituted; (c) refined

$\varepsilon_{\mathrm{a}} \leqslant 20 \%$. A Mohr circle of stress analysis, taking $\varepsilon_{\mathrm{a}}=20 \%$ as an arbitrary failure condition, produced effective angles of shearing resistance $\left(\phi^{\prime}\right)$ values of $30.2 \pm 1.5^{\circ}, 28.9 \pm 1 \cdot 1^{\circ}$ and $30 \cdot 3 \pm 1 \cdot 0^{\circ}$ for undisturbed, reconstituted and refined materials respectively. An effective cohesion $\left(c^{\prime}\right)$ value of zero was assumed for the purpose of these calculations, which is a reasonable approximation, at least for reconstituted and refined peats, with all three materials compressed sheared in a normally consolidated state. Marachi et al. (1983) and Farrell and Hebib 


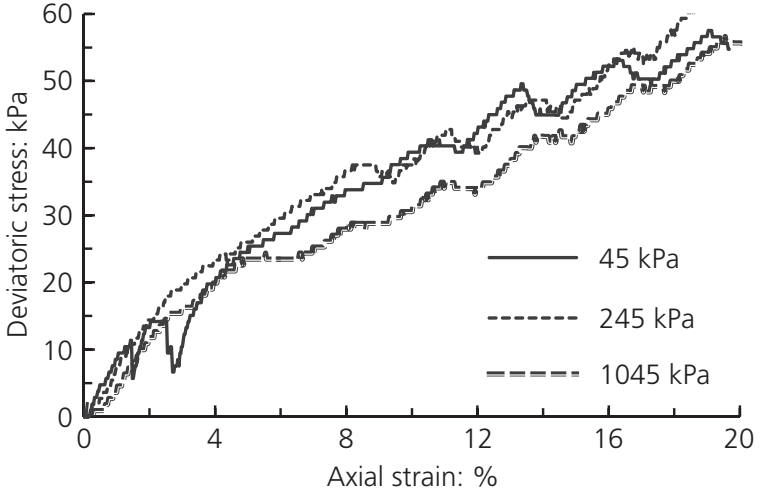

(a)

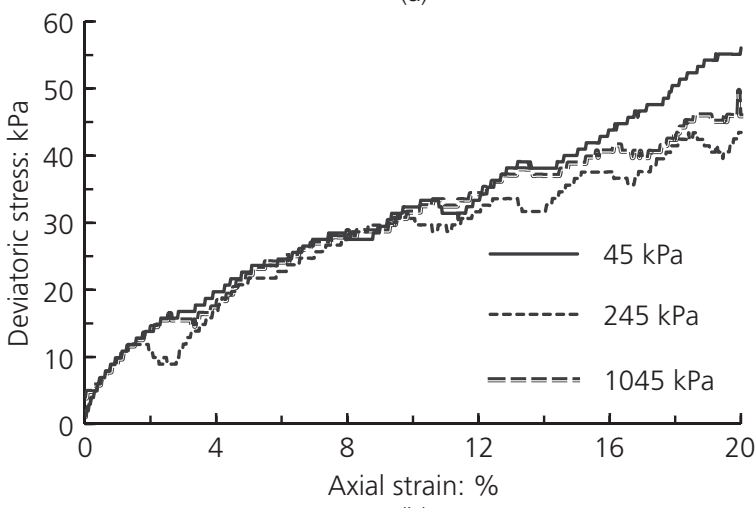

(b)

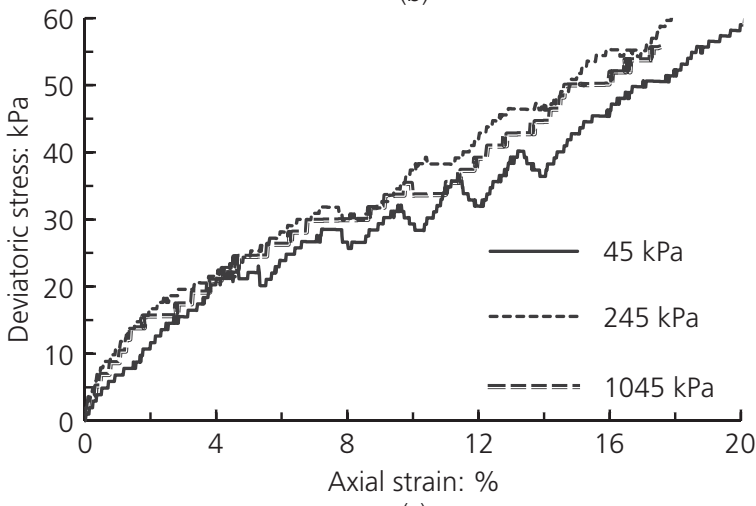

(c)

Figure 7. Deviatoric stress against strain in drained triaxial compression: (a) undisturbed; (b) reconstituted; (c) refined

(1998) have also reported $c^{\prime}=0$ from consolidated-drained triaxial compression testing of fibrous peat.

Higher values of $\phi^{\prime}$ would be deduced for higher strain levels, and vice versa, although no experimental data were recorded to confirm whether or not the shear responses of the different peat materials remain similar for $\varepsilon_{\mathrm{a}} \gg 20 \%$. However, the deduced $\phi^{\prime}$ values in the present study are in line with $\phi^{\prime}=34^{\circ}$ reported by Hollingshead and Raymond (1972) for undisturbed finefibrous to amorphous peat specimens tested in drained triaxial compression under $\sigma_{3}^{\prime}=1.8-8.5 \mathrm{kPa}$. Like the present study, these tests were arbitrarily terminated at $\varepsilon_{\mathrm{a}}=24 \%$, since up to this level the stress-strain curves were also practically linear

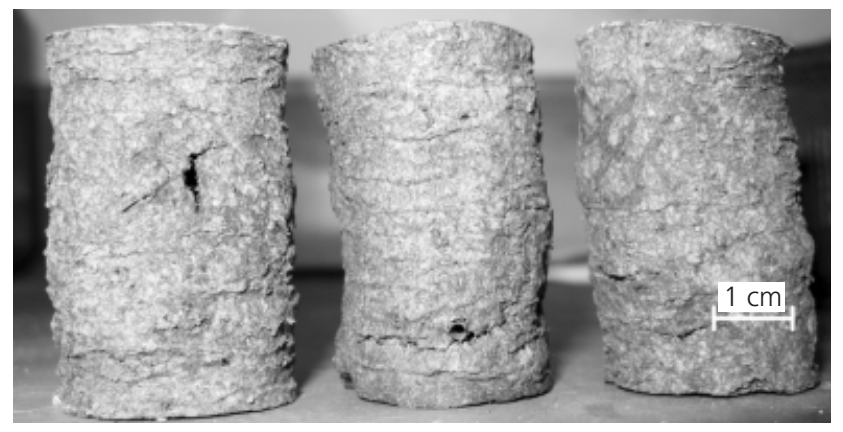

Figure 8. Dried reconstituted specimens after drained triaxial compression under $\sigma_{3}$ (in order, left to right) of 45, 245 and $1045 \mathrm{kPa}$

$\left(E_{\mathrm{v}}^{\prime}=50-200 \mathrm{kN} / \mathrm{m}^{2}\right)$, with none of the specimens mobilising peak deviatoric stress. Furthermore, the undisturbed specimen under $\sigma_{3}=45 \mathrm{kPa}$ and reconstituted specimen under $\sigma_{3}=245 \mathrm{kPa}$ (see Figure 8 ) in the present study did not appear to receive any significant strength enhancement from the Calluna remnants, whose presence was particularly noticeable during the preparation of these specimens.

Given the above observations, the authors concur with Landva et al. (1986) that standard consolidated-drained triaxial compression testing is not of particular value in determining the effective-stress strength properties of peat soils. As regards relating shear strength to effective stress, observations reported in the paper together with Figure 8 indicate that shearing in the normal sense was not taking place for $\varepsilon_{\mathrm{a}} \leqslant 20 \%$, so perhaps it is not surprising that the principle of effective stress could not be examined further or confirmed. There may be scope for using relatively taller triaxial test-specimens (i.e. $H: D \gg 2: 1$ ), which, along with necessary modifications to the triaxial apparatus and instrumentation, would allow for the application of $\varepsilon_{\mathrm{a}}>20 \%$, while still maintaining a reasonable specimen aspect ratio for the possibility of shear failure to occur. This may merit further experimental investigation.

Other laboratory strength-testing methods, including in direct shear, direct simple shear and ring shear apparatus, have been used to determine pertinent undrained and effective-stress strength properties of peat. Direct shear testing was not recommended by Landva et al. (1986), owing to the uncertain stress distribution and mode of specimen deformation. However, it is considered that direct simple shear and ring shear testing give the intrinsic $\phi^{\prime}$ of the constituents, and that higher $\phi^{\prime}$ values recorded in triaxial compression and extension tests on vertically carved samples include effects of the fibre structure (Farrell, 2012; Farrell and Hebib, 1998; Landva and La Rochelle, 1983). Hence, in practice, direct simple shear and ring shear testing produce lower values of $\phi^{\prime}$ for conservative estimates.

\section{Conclusion}

The study emphasises that peat is a difficult and unconventional geomaterial, which presents significant challenges for geotechni- 
cal laboratory testing, and in the interpretation of the experimental data. Another challenge arose in the extreme variability of the peat, which was found to occur under controlled samplepreparation conditions, even for blended peat material. The importance of structure was evident, with the volumetric strain response under both one-dimensional compression and isotropic consolidation clearly related to the performance of fibres. From the point of view of the main aim of the paper, to examine whether the principle of effective stress may be applied to peat soils, then there is no firm conclusion, but high $B$ values measured and volumetric strain observations support it. Saturated pseudo-fibrous peat specimens under $\sigma_{3}^{\prime}=30 \mathrm{kPa}$ (mobilised in isotropically consolidated-drained triaxial compression tests by applying different cell- and back-pressure combinations) were found to produce similar shear resistance and volume change responses, in agreement with the principle of effective stress. However, this study did not get to grips with effective stress per se, which would necessitate further investigations of the full stress-strain-time/stress/strain rate behaviour, noting the effects of soil structure and the compressible fibres. It is also accepted that in situ effective stresses in peat deposits are generally considerably lower than $\sigma_{3}^{\prime}=30 \mathrm{kPa}$, and hence the authors recommend that similar studies be repeated for lower $\sigma_{3}^{\prime}$ values, although this would require more accurate control and measurement of pressure/volume change in the triaxial apparatus.

It was found that consolidated-drained triaxial compression testing of the peat was not of particular value in terms of determining its effective-stress strength properties, since the deviatoric stress continued to increase approximately linearly with axial strain, without reaching a peak value. Hence the calculated effective angle of shearing resistance was strain-level dependent. Furthermore, effects of mini-structure (undisturbed material) and coarse fibre content (reconstituted material) were not significant in terms of mobilised shear resistance in consolidated-drained triaxial compression for $\varepsilon_{\mathrm{a}} \leqslant 20 \%$, when compared with the response of blended peat material.

\section{Acknowledgements}

The authors acknowledge the following contributions of Trinity College Dublin (TCD) personnel to the reported work: Martin Carney and Eoin Dunne in assisting with the geotechnical laboratory tests; Patrick Veale with peat sampling; and Derek Simpson in obtaining the SEM images. The first author gratefully acknowledges a Postgraduate Research Award received from TCD.

\section{REFERENCES}

ASTM (2007) D 4427-07: Standard classification of peat samples by laboratory testing. ASTM International, West Conshohocken, PA, USA.

ASTM (2008) D 1997-91. Standard test method for laboratory determination of the fiber content of peat samples by dry mass. ASTM International, West Conshohocken, PA, USA.

Baird AJ and Gaffney SW (1994) Cylindrical piezometer responses in a humified fen peat. Nordic Hydrology 25(3): 167-182.
Bennethum LS, Murad MA and Cushman JH (1997) Modified Darcy's law, Terzaghi's effective stress principle and Fick's law for swelling clay soils. Computers and Geotechnics 20(3): 245-266.

Bishop AW and Eldin G (1950) Undrained triaxial tests on saturated sands and their significance in the general theory of shear strength. Géotechnique 2(1): 13-32.

BSI (1990a) BS 1377-2: Methods of test for soils for civil engineering purposes. Classification tests. British Standards Institution, Milton Keynes, UK.

BSI (1990b) BS 1377-3. Methods of test for soils for civil engineering purposes. Chemical and electro-chemical tests. British Standards Institution, Milton Keynes, UK.

BSI (1990c) BS 1377-8: Methods of test for soils for civil engineering purposes. Shear strength tests (effective stress). British Standards Institution, Milton Keynes, UK.

Casagrande A (1936) The determination of the preconsolidation load and its practical significance. Proceedings of the $1 s t$ International Conference on Soil Mechanics and Foundation Engineering, Cambridge, MA, USA, vol. 3, pp. 60-64.

Cola S and Cortellazzo G (2005) The shear strength behaviour of two peaty soils. Geotechnical and Geological Engineering 23(6): 679-695.

Crushell PH, Connolly A, Schouten MGC and Mitchell FJG (2008) The changing landscape of Clara Bog: the history of an Irish raised bog. Irish Geography 41(1): 89-111.

Farrell ER (2012) Organics/peat soils. In ICE Manual of Geotechnical Engineering (Burland J, Chapman T, Skinner H and Brown M (eds)). ICE Publishing, London, vol. 1, pp. 463-479.

Farrell ER and Hebib S (1998) The determination of geotechnical parameters of organic soils. Proceedings of the International Symposium on Problematic Soils, IS-TOHOKU 98, Sendai, Japan, vol. 1, pp. 33-36.

Hanrahan ET (1954) An investigation of some physical properties of peat. Géotechnique 4(3): 108-123.

Hanrahan ET, Dunne JM and Sodha VG (1967) Shear strength of peat. Proceedings of the Geotechnical Conference, Oslo, Norway, vol. 1, pp. 193-198.

Hebib S and Farrell ER (2003) Some experiences on the stabilization of Irish peats. Canadian Geotechnical Journal 40(1): $107-120$.

Hemond HF and Goldman JC (1985) On non-Darcian water flow in peat. Journal of Ecology 73(2): 579-584.

Hobbs NB (1986) Mire morphology and the properties and behaviour of some British and foreign peats. Quarterly Journal of Engineering Geology 19: 7-80.

Hollingshead GW and Raymond GP (1972) Field loading tests on Muskeg. Canadian Geotechnical Journal 9(3): 278-289.

Lambe TW and Whitman RV (1969) Soil Mechanics. Wiley, New York, USA.

Landva AO (1980) Geotechnical Behaviour and Testing Peat. Thesis, University of Laval, Québec, Canada.

Landva AO and La Rochelle P (1983) Compressibility and shear characteristics of Radforth peats. In Testing of Peats and 
Organic Soils, ASTM STP 820 (Jarrett PM (ed.)). ASTM International, West Conshohocken, PA, USA, pp. 157-191. Landva AO and Pheeney PE (1980) Peat fabric and structure. Canadian Geotechnical Journal 17(3): 416-435.

Landva AO, Pheeney PE, La Rochelle P and Briaud JL (1986) Structures on peatland: geotechnical investigations. Proceedings of the Symposium on Advances in Peatlands Engineering, Carleton University, Ottawa, Canada, pp. 31-52. Marachi ND, Dayton DJ and Dare CT (1983) Geotechnical properties of peat in San Joaquin Delta. In Testing of Peats and Organic Soils, ASTM STP 820 (Jarrett PM (ed.)). ASTM International, West Conshohocken, PA, USA, pp. 207-217.

McGeever J (1987) The Strength Parameters of an Organic Silt. MSc thesis, University of Dublin, Trinity College Dublin, Dublin, Ireland.

Mesri G and Ajlouni M (2007) Engineering properties of fibrous peat. Journal of Geotechnical and Geoenvironmental Engineering, ASCE 133(7): 850-866.

Monte JL and Krizek RJ (1976) One-dimensional mathematical model for large-strain consolidation. Géotechnique 26(3): 496-510.

O'Kelly BC (2004) Accurate determination of moisture content of organic soils using the oven drying method. Drying Technology 22(7): 1767-1776.

O'Kelly BC (2005a) Oven-drying characteristics of soils of different origins. Drying Technology 23(5): 1141-1149.

O'Kelly BC (2005b) Consolidation properties of a dewatered municipal sewage sludge. Canadian Geotechnical Journal 42(5): 1350-1358.

O'Kelly BC (2008) Geotechnical properties of a municipal water treatment sludge incorporating a coagulant. Canadian Geotechnical Journal 45(5): 715-725.
O'Kelly BC (2009) Development of a large consolidometer apparatus for testing peat and other highly organic soils. Suo - Mires and Peat 60(1-2): 23-36.

O'Kelly BC (2013) Characterisation and undrained strength of amorphous clay. Proceedings of the Institution of Civil Engineers - Geotechnical Engineering, http://dx.doi.org/ 10.1680/geng.11.00025.

Pichan SP and O'Kelly BC (2012) Effect of decomposition on the compressibility of fibrous peat. In Proceedings of GeoCongress 2012: State of the Art and Practice in Geotechnical Engineering, GSP 225 (Hryciw RD, Athanasopoulos-Zekkos A and Yesiller N (eds)). ASCE, Reston, VA, USA, pp. 43294338.

Pichan SP and O'Kelly BC (2013) Stimulated decomposition in peat for engineering applications. Proceedings of the Institution of Civil Engineers - Ground Improvement, http:// dx.doi/10.1680/grim.12.00003.

Skempton AW and Petley DJ (1970) Ignition loss and other properties of peats and clays from Avonmouth, King's Lynn and Cranberry Moss. Géotechnique 20(4): 343-356.

Terzaghi K (1923) Die Berechnung der Durchlässigkeitsziffer des Tones aus dem Verlauf der hydrodynamischen Spannungserscheinungen. Sitzungsberichte der Deutschen Akademie der Wissenschaften in Wien, MathematischNaturwissenschaftliche Klasse, Abt. 2a 132: 105-124 (in German).

Yamaguchi H, Ohira Y, Kogue K and Mori S (1985) Undrained shear characteristics of normally consolidated peat under triaxial compression and extension tests. Soils and Foundations 25(3): 1-18.

Yang J and Dykes AP (2006) The liquid limit of peat and its application to the understanding of Irish blanket bog failures. Landslides 3(3): 205-216.

\footnotetext{
WHAT DO YOU THINK?

To discuss this paper, please email up to 500 words to the editor at journals@ice.org.uk. Your contribution will be forwarded to the author(s) for a reply and, if considered appropriate by the editorial panel, will be published as a discussion in a future issue of the journal.

Proceedings journals rely entirely on contributions sent in by civil engineering professionals, academics and students. Papers should be 2000-5000 words long (briefing papers should be 1000-2000 words long), with adequate illustrations and references. You can submit your paper online via www.icevirtuallibrary.com/content/journals, where you will also find detailed author guidelines.
} 